九州大学学術情報リポジトリ

Kyushu University Institutional Repository

\title{
Transformation of silage-making Lactobacillus strains by electroporation with plasmid vectors
}

Fan, Guiwen

Microbial Genetics Division, Institute of Genetic Resources, Faculty of Agriculture, Kyushu University

Takahashi, Eiji

Microbial Genetics Division, Institute of Genetic Resources, Faculty of Agriculture, Kyushu University

Doi, Katsumi

Microbial Genetics Division, Institute of Genetic Resources, Faculty of Agriculture, Kyushu University

Matsuo, Shorin

Microbial Genetics Division, Institute of Genetic Resources, Faculty of Agriculture, Kyushu University

他

https://doi.org/10.5109/24267

出版情報：九州大学大学院農学研究院紀要. 43 (1/2)，pp.217-225，1998-11. Kyushu University バージョン：

権利関係 : 


\title{
Transformation of silage-making Lactobacillus strains by electroporation with plasmid vectors
}

\author{
Guiwen Fan, Eiji Takahashi, Katsumi Doi, Shorin Matsuo, \\ Osamu Tanaka*, Sadahiro Ohmomo*, and Seiya Ogata
}

\author{
Microbial Genetics Division, Institute of Genetic Resaurces, Faculty of Agriculture, \\ Kyushu University, Fukuoka 812-8581, Japar \\ (Received July 30, 1998 and accepted August 7, 1998)
}

\begin{abstract}
Several newly isolated strains of Lactobacillus for silage fermentation were transformed with plasmid vectors, $\mathrm{p}(\mathrm{KK} 12$ and $\mathrm{pSA} 3$, by electroporation. Transformation efficiency depended on the electric field strength, time-constant, polyethyleneglycol (PEG) molecular weight in electroporation buffer and the incubation temperature after exposition of pulses. Transformation of $L$. pentosus NGRI0225 resulted in the maximum transformation efficiency of $5.7 \times 10^{\circ}$ transformants per $\mu \mathrm{g}$ DNA of pGKI2 with an electric field strength of $7.0 \mathrm{kV} / \mathrm{cm}$, time-constant of $6.2 \mathrm{~ms}$ and $30 \%$ (W/V) of PEG 1000. Plasmid DNAs isolated from all transformants did not show any detectable rearrangements or deletions under these conditions.
\end{abstract}

\section{INTRODUCTION}

Lactobacillus species are gram-positive bacteria, which are used as inocula of grass silage, meat and lactic acid beverages. In spite of their importance, very little is known about their efficient transformation systems. Polyethylene glycol (PEG) induced protoplast transformation (Leer et al., 1987; Badii et al. 1989) and transfection (Cosby et al., 1988) of Lactobacilli are possible but are not very efficient.

Electroporation is a relatively new method for bacterial transformation that is rapidly gaining acceptance. This method has opened the way to genetic analysis and manipulations for many kinds of bacteria. Electroporation for Lactobacilli has also been described (Aukrust and Nes 1988; Luchansky et al., 1988; Josson et al., 1989; Badii et al., 1989; Bringel et al, 1989), but the transformation efficiencies obtained were generally very low. The optimal method of transformation ( $5 \times 10^{6}$ transformants/ug plasmid DNA) has been obtained by Bringel et al. (1990).

We attempted to employ the newly isolated strains of Lactobacillus for silage fermentation, and systematically investigated the effects of several factors on the transformation efficiency. This paper describes the optimal transformation of these Lactobacillus strains by electroporation with plasmids, pGK12 and pSA3.

\section{MATERIALS AND METHODS}

\section{Bacterial strains and plasmids}

Lactobacillus strains used in this study were $L$. plantarum NGRI0315, L.

\footnotetext{
*National Grassland Research Institute, Nishi-nasuno, Tochigi 329-2747, Japan
} 
plantarum NGR10529, L. pentosus NGRI0225, L. pentosus NGRI0524, L. rhamnosus NGRI0110 and L. plantarum IFO3070. Strains NGRI were isolated from grass silages gathered from south-west Japan (Tanaka et al., 1994; 1998; Doi et al., 1997). These strains were grown in MRS (Difco) broth at $37^{\circ} \mathrm{C}$. The MRS agar medium containing antibiotics erythromycin and lincomycin was also used as the selection medium for transformants.

Plasmids pSA3 (10.2kbp, Emr; Dao et al., 1988) and pGK12 (4.4kbp, Emr; Kok et al., 1984) were kindly provided by Dao M. L (University of Oklahoma Health Sciences Center, U. S. A) and Kok J (Lniversity of Groningen, Netherlands), respectively.

\section{Electroporation protocol.}

Electroporation was done by using a BTX transformation system ECM600 (San Diego, Calif, USA). A pulse produced by discharge of a capacitor has an exponential decay waveform. Time-constant depends on the total resistance $(R$, in $\Omega$ )-capacitance $(C$, in F) of the system: $\tau=\mathrm{R} \times \mathrm{C}$. Therefore, $\tau$ describes the shape of the decay waveform and is the time required for the electric field strength $(\mathrm{V} / \mathrm{cm})$ to decline to $1 / \mathrm{e}(36.8 \%)$ of the initial value.

To obtain competent cells, the cells were cultured in MRS broth at $37^{\circ} \mathrm{C}$ for $12 \mathrm{hr}$, and then transferred to MRS containing $1 \%(\mathrm{w} / \mathrm{v})$ of glycine and grown at $32^{\circ} \mathrm{C}$ for $2 \mathrm{hr}$, until O.D. at $600 \mathrm{~nm}$ of $0.4-0.6$. The cells were harvested by centrifugation at $4^{\circ} \mathrm{C}$, $6000 \mathrm{rpm}$. After the cells were washed with bidistilled water sterilized by autoclaving, the pellet was resuspended in a solution of $30 \%(\mathrm{w} / \mathrm{v})$ PEG and then aliquots were stored at $-85^{\circ} \mathrm{C}$ until use.

A part $(100 \mu \mathrm{l})$ of the cell suspension was thawed on ice and mixed with $1 \mu \mathrm{l}$ of plasmid DNA dissolved in TE buffer. The mixed suspensions were transferred to ice-cooled electroporation cuvettes (2-mm electrode gap) and then exposed to a single electrical pulse. The cuvettes were then placed on ice for $10 \mathrm{~min}$, after which they were transferred to MRS medium and incubated at $32^{\circ} \mathrm{C}$ or $37^{\circ} \mathrm{C}$ for $4 \mathrm{hr}$ to allow expression of erythromycin-resistant gene, and they were then spreaded on MRS agar medium containing $5 \mu \mathrm{g}$ of erythromycin (Sigma) per $\mathrm{ml}$ and $10 \mu \mathrm{g}$ of lincomycin (Sigma) per $\mathrm{ml}$ for incubation at $32{ }^{\circ} \mathrm{C}$ for 2 days.

\section{Isolation and analysis of plasmids DNA}

Erythromycin-resistant transformants were grown at $37^{\circ} \mathrm{C}$ for $12 \mathrm{hr}$ in MRS medium containing $10 \mu \mathrm{g}$ of etythromycin per ml. Plasmids were isolated as described elsewhere (Anderson and McKay 1983) and analyzed by agarose gel electrophoresis.

\section{RESULTS AND DISCUSSION}

\section{Effect of electric field strength}

The electric field used for electroporation is important and the optimal electric field depends on the bacterial species and strains.

To determine the optimal electric field for electroporation, we exposed the cells to single decayed pulses with electric field strength from $5 \mathrm{kV} / \mathrm{cm}$ to $8 \mathrm{kV} / \mathrm{cm}$ when capacitance was fixed at $25 \mu \mathrm{F}$. As shown in Fig. 1, the maximum transformation 


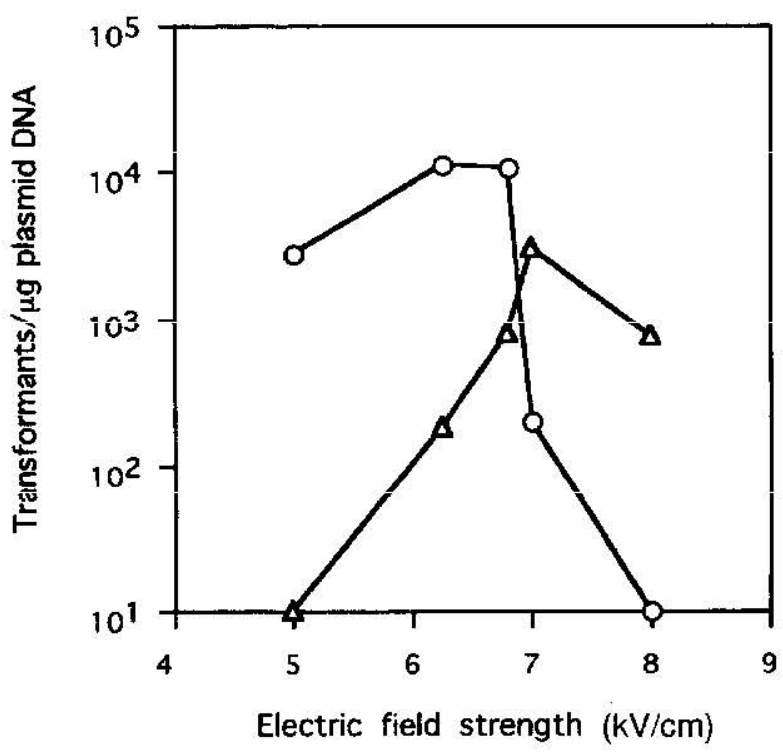

Fig. 1. Effect of electric field strength on transformation efficiency of Lactobacillus plantarum NGRI0315 and Lactobacillus pentosus NGRI0225 with plasmid pGK12. The time-constant was fixed at $6.2 \mathrm{~ms}$.

Symbols: O : Lactobacillus plantarum NGRI0315

$\Delta$ : Lactobacillus pentosus NGRI0225

efficiency was obtained for $L$. plantarum NGR10315 and $L$. pentosus NGR10225: the former was $1.1 \times 10^{4}$ transformants per $\mu \mathrm{g}$ pGK12 and the latter was $3.0 \times 10^{3}$ transformants per $\mu \mathrm{g}$ pGK12 at $6.25 \mathrm{kV} / \mathrm{cm}, 7.0 \mathrm{kV} / \mathrm{cm}$, respectively. Transformation efficiency with electric field strength of $8 \mathrm{kV} / \mathrm{cm}$ decreased because of the irreversible death of cells caused by higher electric puisation (Chassy and Flickinger 1987). The amplitude of the electric field therefore had an effect on the efficiency of electroporation. There was a difference in optimal electric field between $L$. plantarum NGRI0315 and $L$. pentosus NGRI0225. This result indicated that the optimal electric field was different for each strain.

\section{Effect of time-constant}

The optimal time-constant was examined for the resistance range of between $186 \Omega$ and $720 \Omega$ when capacitance was fixed at $25 \mu \mathrm{F}$, resulting in time-constants of 4.6 to $18 \mathrm{~ms}$. Maximum transformation efficiency was obtained with $6.2 \mathrm{~ms}$ for $L$. pentosus NGRI0225 and L. planatarum NGRI0315, as shown in Fig. 2. The time-constant had a common effect in both strains. The transformation efficiency was decreased gradually over the optimum time-constant, $6.2 \mathrm{~ms}$. This might be due to cell death or DNA damage occurring at higher time-constant (Bringel et al., 1990) 


\section{Effect of PEG molecular weight in electroporation buffer}

Effect of PEG molecular weight in electroporation buffer on transformation efficiency was also investigated. PEG molecular weight was varied from 1000 to 6000 when its concentration was held at $30 \%(\mathrm{w} / \mathrm{v})$. As shown in Fig. 3, the optimal PEG molecular

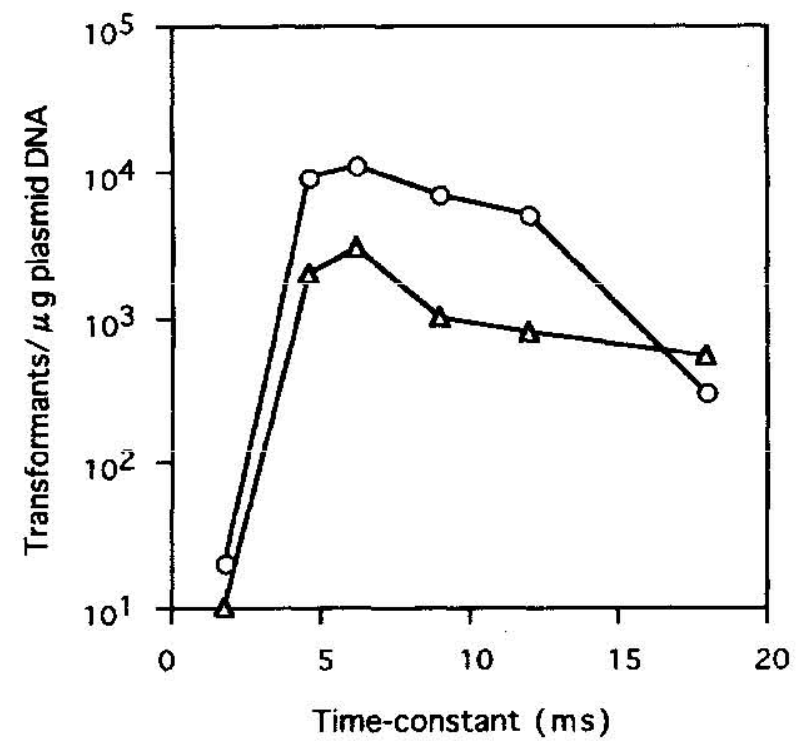

Fig. 2. Effect of time-constant on transformation efficiency of Lactobacillus strains NGRI0225 and NGRI0315 with plasmid pGK12. The elcctric field strength of Lactobacillus strains NGRI0225 and NGRI0315 were $7.0 \mathrm{kV} / \mathrm{cm}$ and $6.25 \mathrm{kV} / \mathrm{cm}$, respectively, and capacitance was fixed at $25 \mu \mathrm{F}$.

Symbols: O : Lactobacillus plantarum NGRI0315

$\Delta$ : Lactobacillus pentosus NGRI0225

weight was obtained with PEG 1000 and transformation efficiency of $L$ plantarum NGRI0315 was $3.6 \times 10^{4}$ transformants/ $\mu$ g pGK12 DNA. Transformation efficiency distinctly decreased with increasing PEG molecular weight, PEG 6000 had no effect. Similar observations were reported in Lactobacillus hilgardii (Josson et al., 1989), Bacillus thuringiensis (Mahillon et al., 1989) and Streptomyces rimosus R6 (Pigac et al., 1995). The positive effect of PEG would be attributed to volume exclusion, interactions with cell membranes, and the increased survival of electroporated cells.

\section{Effect of incubation temperature after exposition of pulse}

Effect of incubation temperature after exposition of pulse was also estimated. After the cells were exposed to a single pulse, they were incubated for $4 \mathrm{hr}$ to allow for expressions of erythromycin-resistant gene. the cultures were incubated at $32^{\circ} \mathrm{C}$ or 


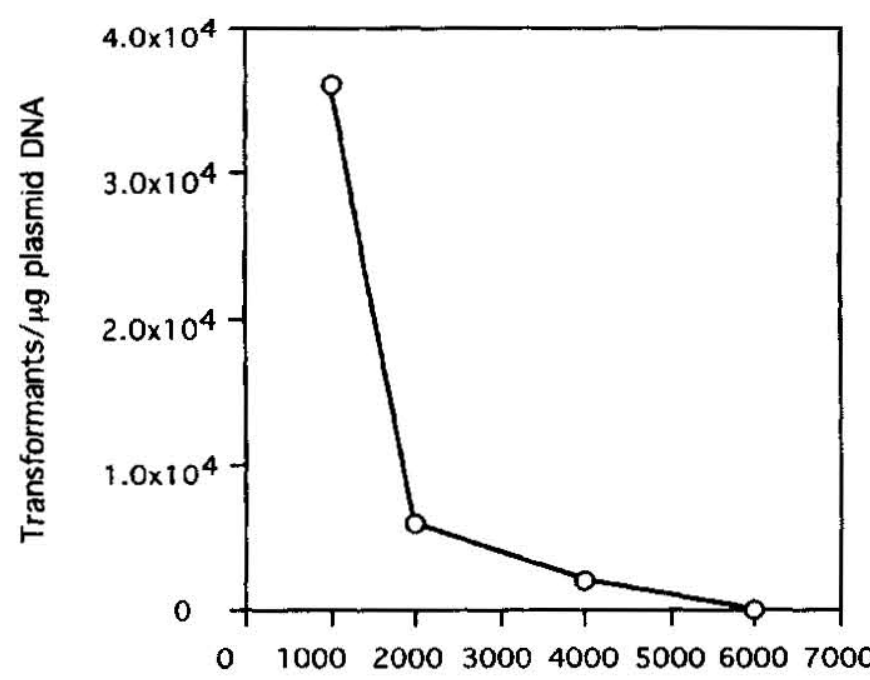

\section{PEG molecular weight}

Fig. 3. Effect of PEG molecular wcight on transformation efficiency of NGRI0315 with plasmid pGK12. PEG concentration was kept at $30 \%$ (W/V).

Table 1. Effeci of incubation temperature after exposition of a pulse on transformation efficiency of lactobacillus pentosus NGIRI0225 and lactobacillus plantarum NGRI0315 with plasmids pGK12 and pSA3.

\begin{tabular}{|c|c|c|c|}
\hline \multirow{2}{*}{ Strains } & \multirow{2}{*}{ Plasmids } & \multicolumn{2}{|c|}{ Transformantsi $\mu g$ plasmid DNA } \\
\hline & & $32^{\circ} \mathrm{C}$ & $37^{\circ} \mathrm{C}$ \\
\hline \multirow{2}{*}{ NGRI0315 } & pGK12 & $2.8 \times 10^{\prime \prime}$ & $1.1 \times 10^{4}$ \\
\hline & pSA3 & $4.2 \times 10^{3}$ & $0-10$ \\
\hline \multirow{2}{*}{ NGRI0225 } & pGK12 & $1.2 \times 10^{3}$ & $3.0 \times 10^{9}$ \\
\hline & pSA:3 & $5.5 \times 10^{1}$ & $0-20$ \\
\hline
\end{tabular}

$37^{\circ} \mathrm{C}$, the results are shown in Table 1 . When the cells were incubated at $32^{\circ} \mathrm{C}$, the transformation efficiencies by both plasmids pGK12 and pSA3 were high $\left(2.8 \times 10^{3}-5.5 \times\right.$ $10^{3}$ transformants/ $\mu$ g plasmid DNA). However when the cells were incubated at $37^{\circ} \mathrm{C}$, the transformation efficiency was high only in using the pGK12, but transformants were hardly obtained when using the pSA3. These results indicated that the transformation efficiencies depended on incubation temperature after exposition of a pulse and type of plasmids. 


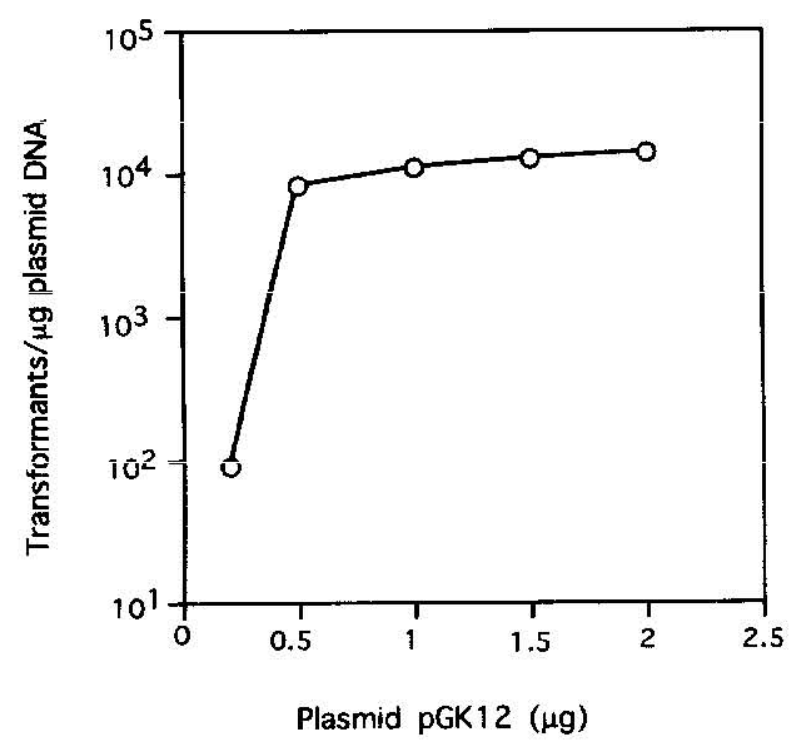

Fig. 4. Effect of DNA concentration on transformation efficiency of Lactobacillus plantarum NGRI0315 with plasmid pGK12. Plasmid DNA was added to the cells suspended in electroporation-buffer. A $100 \mu \mathrm{l}$ of suspension was exposed to single pulse of electric field strength of $6.25 \mathrm{kV} / \mathrm{cm}$. The capacitance was fixed at $25 \mu \mathrm{F}$.

\section{Effect of piasmid $\mathbf{D}$ ǸA concentration}

Transformation efficiency using electroporation was highly dependent on DNA concentration. As shown in Fig. 4, there was a linear relationship between transformation efficiency and INA concentration ranging from 0.2 to $0.5 \mu \mathrm{g} / \mathrm{ml}$ of pGK12 DNA. However, iransformation efficiency was hardiy increased when DNA concentration was more than $0.5 \mu \mathrm{g} / \mathrm{ml}$. Similar results were obtained by Bringel et al. (Bringel et al., 1990)

\section{Plasmids analysis of transformants}

Plasmids from various transformants were analyzed by agarose gel electrophoresis. As shown in Fig. 5, all transformants analyzed had plasmid DNAs with the same mobilities as those of the authentic plasmid DNAs. The restriction patterns of plasmid DNAs using EcoRV and HindIII were also identical in all transformants (data not shown). The results indicated that the plasmid DNAs in the transformants were replicated exactly and did not suffer any significant modifications such as rearrangements or deletions. 


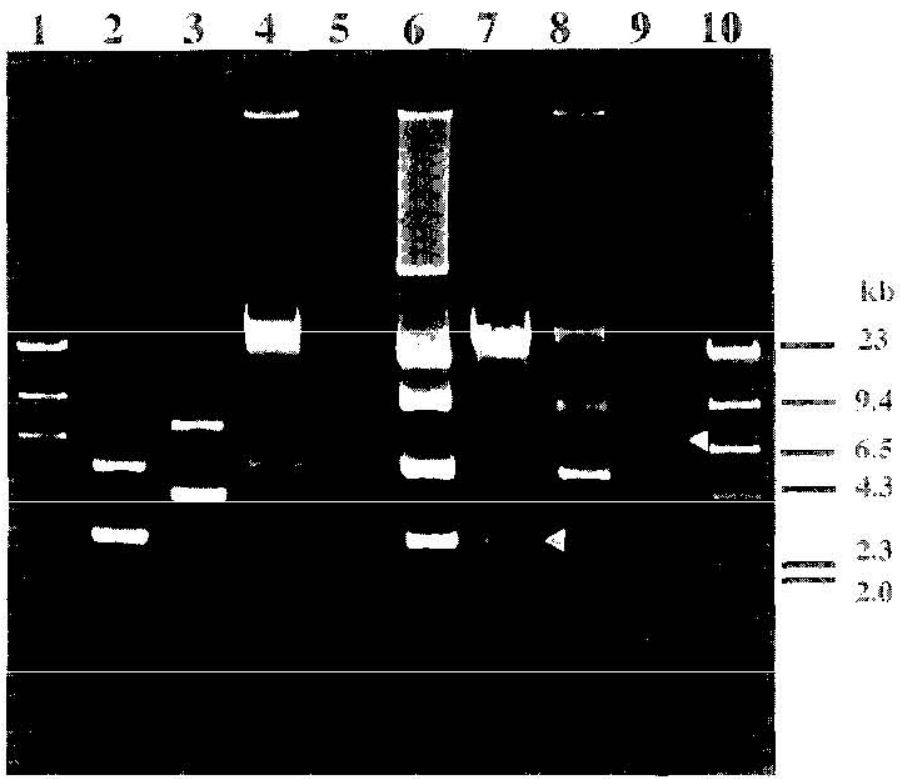

Fig. 5. Agarose gel electrophoresis analyses of plasmids from Lactobacillus plantarnm NGRI0315, Lactobacillus pentosus NGRIO225 and $E$. coli. HB101. Lane 1 and 10, HindIII-digested $\lambda$ DNA; Jane 2, pGK12 (HB101); Iane 3, pSA3 (HB101); Lane. 4, Wild type NGRI0315; Lane 5, Wild type NGIRI0225; Lane 6, pGK12 (NGRI0315); Lane 7, pGK12 (NGRl0225); Lane 8, pSA3 (NGRI0315); Lane 9, pSA3 (NGRI0225).

Table 2. Transformation efficiency of several silage-making Lactobacillus strains with plasmids p $\mathrm{GK} 12$ and $\mathrm{pSA} 3$.

\begin{tabular}{|c|c|c|}
\hline Strains & $\begin{array}{l}\text { Transformant.sing } \\
\text { of plasmid pGK12 }\end{array}$ & $\begin{array}{l}\text { Transformants/ing } \\
\text { of plasmid pSA? }\end{array}$ \\
\hline Lactobacillus plantarum NGRI 0315 & $1.1 \times 10$ & $4.2 \times 10^{3}$ \\
\hline Lactobacillus plantarum NGLI 0529 & $2.2 \times 10^{6}$ & $3.3 \times 10^{2}$ \\
\hline Lactobacillus pentosus N(XRI 0225 & $3.0 \times 10^{3}\left(5.7 \times 10^{*}\right)^{*}$ & $5.4 \times 10^{3}$ \\
\hline Lactobacillus pentosus NGRI 0524 & $3.1 \times 10^{3}$ & $3.9 \times 10^{\circ}$ \\
\hline Lactobacillus rhamnosus NGRI 0110 & $1.0 \times 10^{\circ}$ & $1.2 \times 10^{2}$ \\
\hline Lactobacillus plantamm IFO 3070 & $1.0 \times 10^{\circ}$ & $1.0 \times 10^{\circ}$ \\
\hline
\end{tabular}




\section{Application to other Lactobacillus strains}

We attempted to apply the above condition of electroporation obtained for Lactobacillus strains NRG10225 and NGRI0315, to several other silage-making Lactobacillus strains. As shown in Table 2, L. rhamnosus NGRI0110, L. plantarum. 3070, L pentosus NRGI0524 and L. plantamum NGRI0529 were able be transformed with pGK12 and pSA 3 at various transformation effeciencies. Their transformation efficiencies ranged from $1.0 \times 10^{*}$ to $3.1 \times 10^{\circ}$ transformants per $\mu$ g plasmid DNA. In order to extlude restriction modification (R/M) systems in $E$. coli, transformation was carried out with plasmid pGK12 isolated from a transformant of $L$. pentosus NGRI0225. As shown Table 2 , datum in parenthesis of higher transformation efficiency was obtained with $5.7 \times 10^{5}$ transformants per $\mu \mathrm{g}$ plasmid DNA.

These results demonstrated that plasmid DNA could be efficiently introduced into silage-making Lactobacillus strains by electroporation. This technique is simple, rapid and applicable to many kinds of silage-making Lactobacillus strains. It will become a useful technique for further research in the molecular genetics of silage-making Laclobacillus strains

\section{REFERENCES}

Anderson, Г). G and I. L. Mckay 1983 Simple and rapid method for isolating large plasmid DNA from lactic streptococei. Appl Environ Microbiol, 46: $549-552$

Aukrust, T. and I. F. Nes 1988 Transformation of Lactobacillus plantarym with the plasmid p'lv1 by clcctroporation. FEMS Microbiol. Let, 52: 127-131

Bringel, F, and .J. C. Hubert 1990 Optimized transformation by electroporation of Lactobacillas plantarum strains with plasmid vectors. Appl. Microbiol. Biotechnol., 33: 664-670

Bhowmik, T. and J. L. Steele 1993 Development of an elcctroporation procedure for gene disruption in Lactobacillus heweticus CNRZ32. I. Gerz. Microbiol, 139: 1433-1439

Chassy, B. M. and J. L. Flickinger 1987 Transformation of Lachobacillus cased by electroporation. FEMS Microbiol Lett., 44: 173-177.

Dao, M. L., and J. J. F'errelli 1985 Streptococeus-Escherichia coli shuttle vector pSA3 and its use in the cloning of streptococcal genes, Appl. Envirort. Microbiol., 49: 115-119

Doi, K., T. Eguchi., O. Tanaka., K. Mori., S. Ohmomo and S. Ogala 1997 Genetic Fngineering of Silagc-Making Lactobacilli. Seibutsu-Kogaku Kaishi (in Japanese), 75: $361-363$

Pigac, J and H Schrempl 1995 A Simple: and Rapid Method of transformation of Streptomyces rimosus R6 and Other Strcptomycetes by Elcctoroporation. Appl. Enwiron. Mocrobiol, 61: 352-256

Hashiba, H., R. Takiguchi., S. Ishii and K. Aoyarna 1990 Transformation of Lactobacillus helveticus subsp. jugurti with plasmid pLHR by clectroporation. Agric. Biol. Chem., 54: 1537-1541

Holo, H. and 1. F. Nes 1989 High-Frequency Transformation, by Elcctroporation, of Lactococcus lactis subsp. crenoris Grown wilh Glycine in Osmilically Stabilized Media. Appl Environ. Microbiol., $\mathbf{5 5}$ : $3119-3123$

Josson, K., T. Scheirlinck, F. Michiels, C. Platteeuw, P. Stanssens, H. Joos, P. Dhaese, M. Zabeau and J. Mahillon 1989 Characterization of a Gram-positive broad-host-range plasmid isolated from Lactobacillus hilgardit. Plasmid., 21: 9-20

Kanatoni, K., K. Yoshida, T. Tahara, K. L. Yamada, H. Miura, H. Sakamoto 1992 Transformation of Lactobacillus acidophilus TK8912 by electroporation with pLLA105E plasmid. I. Ferm. Bioeng., 74: $358-362$

Kok, J., J. M. B. M van der vossen and G. Venema 1984 Construction of plasmid cloning vectors for the lactic streptococci which also replicate in Bacillus subtilis and Escherichia coli. Appl. Environ. Microbiol., 48: 726-731

Lucharisky, I. B., P. M. Muriana, and T. R. Klacnhammer 1988 Application of elcctroporation for transfer of plasmid DNA to Lactobacillus, lactococcus, Leuconostoc, Lisieria, pediococcus, Bacillus, 
Staphylococcus, Enterococcus and Propionibacterium. Mol. Microbiol., 2: 637-646

Mahillon, J., W. Chungjatupornchai, J. Decock, S. Dierickx, F. Michiels, M. peferoen, and H. Joos 1989 Transformation of Bacillus thuringiensis by electroporation. FEMS Microbiol. Lelt., 60: 205-210

Powell, I. B., M. G. Achen, A. J. Hillier, and B. E. Davidson 1988 A simple and rapid method for genetic: transformation of Lactic Streptococci by electroporation. Appl Environ Microbiol., 54: 655-660

Tanaka, O., H. Kimura, E. Takahashi, S. Ogata and S ohmomo 1994 Screening of lactic acid bacteria for silage inoculants by using a model system of silage fermentation. Biosci Biotech Biochem., 58 : $1412-1415$

Tanaka, O and H. Ohmomo 1998 Lactic Acid Productivily of the Selected Strains of the Genus Lactobacillus in Laboratory-scale Silages. Grassland Sci, 43(4): 374-379

Walker, D. C., K. Aoyama and T. R. Klaenhammer 1996 Electroporation of Lactobacillus acidophilus Group A1. FEMS Microbiol. Lett., 138: 233-237 